Çukurova Üniversitesi Mühendislik Mimarlık Fakültesi Dergisi, 31(2), ss. 327-341, Aralık 2016

\title{
Bebek Bezi Üretimi
}

\author{
Seval UYANIK ${ }^{1}$, PInar DURU BAYKAL ${ }^{* 2}$ \\ ${ }^{1}$ Gaziantep Üniversitesi, Teknik Bilimler Meslek Yüksek Okulu, Tekstil Bölümü, Gaziantep \\ ${ }^{2}$ Çukurova Üniversitesi, Mühendislik Mimarlık Fakültesi, Tekstil Mühendisliği Bölümü, Adana
}

Geliş tarihi: 13.06 .2016

Kabul tarihi: 23.11 .2016

$\ddot{\mathbf{O} z}$

Tek kullanımlık bir ürün olan bebek bezi, tüm toplumlar için bebek ve çocuk sağlığı açısından çok önemli bir üründür. Günümüzdeki bebek bezleri öncekilere göre çok daha ince ve emici olup cilt tahrişlerini ve bulaşıcı hastalıkları önlemede oldukça etkilidirler. İşlevleri farklı materyal ve tabakaların birleşimiyle elde edilen bezlerde dokunmamış (nonwoven) yüzeyler geniş kullanım alanına sahiptirler. Modern bebek bezi makineleri işlem aşamalarının kontinü olarak gerçekleştirildiği 20-45 metre uzunluğunda makinelerdir. Hijyenik ürün pazarında atılabilir bezlerin payı \%50'ye yakındır. Pazar hâkimiyeti açısından ise dünyada ABD ve Çin'li firmalar ön plana çıkmıştır. Türkiye'de ise özellikle İstanbul civarı ve Gaziantep'te yoğun bir şekilde bebek bezi üretimi yapılmaktadır. Bebek bezi ihracatının gittikçe arttığ1 ülkemizde ihracatın çok büyük bir kısmı Irak'a yapılmaktadır.

Anahtar Kelimeler: Bebek bezi, Sürekli bebek bezi makinesi, Dokunmamış yüzeyler, Bebek bezi ihracat1

\section{The Production of Baby Diaper}

\begin{abstract}
Baby diaper which is disposable is an important product in terms of infant and child health in all societies. Nowadays, baby diapers are much thinner and absorbent than previous diapers and they are very effective in preventing skin irritation and infectious diseases. Nonwovens have wide using area in diapers which are obtained by combination of the materials and layers which have different functions. Modern baby diaper machines which carry out process steps as continuous are from 20 to 45 meters in length. The share of disposable diapers is close to $50 \%$ in the market of hygienic products. In terms of market dominance, the US and Chinese firms have come to the fore in the world. In Turkey, especially in Istanbul vicinity and Gaziantep production of baby diapers are made intensively. A large proportion of exports are made to Iraq in our country which has increasingly exporting of the baby diaper.
\end{abstract}

Keywords: Baby diaper, Continuous baby diaper machine, Nonwoven, Baby diaper export

\footnotetext{
* Sorumlu yazar (Corresponding author): Pınar Duru BAYKAL, pduru@cu.edu.tr
} 


\section{GíRiș}

1930'lardan önce çocuk bezi temel olarak ya pamuk tabanlı nervürlü havlu ya da pamuk muslin tipi malzemeden üretilmiştir. Kare şeklindeki bu bezler bebeğin etrafına sarılarak ve güvenli tutaçlarla sabitlenerek kullanıldı. Bebek bezi sonra elastik bacak arası olan yeniden kullanılabilir plastik veya kauçuk pantolonla kapland. 1930'ların sonlarında bezin aralarında kullanılan dokunun (tissue) ilk şekilleri İsveç'te tanıtıldı. 1936 ve 1942 arasında Pauliström Bruk tarafından kauçuk pantolon şeklindeki bu bezlerin selülozik ped içeren değişik dizaynları ortaya çıkarıldı. 1950 yılında şirket kauçuk pantolon şeklindeki bezin içine yerleştirilmiş ve dış katmanı ağ tabanlı olan ağartılmış selülozik vatka içeren yeni bir sürümünü tanıttı. Aynı yıl Johnson \& Johnson, plastik alt tabakalı ve rslak mukavemeti yüksek dokulu selülozik vatkaya dayalı dikdörtgen pedini tanıttı. 1957'de Mölnlycke örülmüş ağla kaplı paralanmış odun hamurundan (selülozdan) oluşan ara tabakayı tanıttı. Bebek bezindeki en yeni buluş ise 1950'de duş perdesini keserek bezin etrafina plastik kılıf yapan Marion Donovan isimli kişinin bezin bebeği üzerinden kaymasını önlemek için çıt çıt kullanması olmuştur. Bezin bu şekli önemli bir başarıydı ve zamanla çalışan annelerin artmasıyla kabul gördü. 1961 yılında Procter \& Gamble ABD tarafindan plastik alt tabaka (backsheet) ve nonwoven üst tabaka (topsheet) arasina yerleştirilen selüloz vatkalı bez tipleri tanıtılmaya başlandı. Sonraki gelişmeler, yapışkan bant ekleme ve plastik backsheets kullanımıyla devam etti.

1980'lerin ortalarındaki gelişmeler ise odun hamuruna eklenen geliştirilmiş süper emici polimerlerin ilavesi ve bunların yanı sıra ön ve yan bantlar, elastik bel gibi yenilikler oldu. 1989 yılında Kimberly-Clark tarafindan pantolon şeklindeki ilk alıştırma pantolonunun tanitılmasıyla 1991 yılında bu ürünler çocuğun tuvalet eğitimi aşamasında pazara girmiştir. Alıştırma pantolonu ve pantolon çocuk bezi arasındaki ayırım emme kapasitesi ile ilgili olup alıştırma pantolonu daha sınırlı emme kapasitesine sahiptir. Tek kullanımlık bebek bezleri (Şekil 1) bugün öncekilere göre çok daha ince ve emici olup sonuç olarak daha etkilidir. $\mathrm{Bu}$ yeni geliştirilen ürünler, bebek ve anne için daha fazla kullanım kolaylığı sağlamaktadır. Ayrıca, bu ürünleri kullanan çocuklarda cilt tahrişi belirgin olarak azalmıs ve bakım ortamlarında çocuklar arasında bulaşıcı hastalıkların vavılmasında bir düsüs gözlenmiștir [11. Bunun yanı sıra beze uygulanan koku apreleri de bezin güzel kokmasını ve ürün değerinin artmasını temin etmektedir [2]. Bebek bezi ile ilgili son çalışmalar bebeğin sağlığını koruma ve konforunu artırma açisından kullanilabilecek hammaddeler üzerine yoğunlaşmıştır. Yapılan bir çalışmada Chitosan karışımı liflerden spun-lace metoduyla elde edilen dokunmamış (nonwoven) materyallerin iyi geçirgenlik, su iletimi, yalıtım, antibiyotik koruma, koku önleme, antimikrobiyal etki fonksiyonları sağladığı için bebek bezinde iç tabaka olarak kullanılabileceği belirtilmiştir [3].

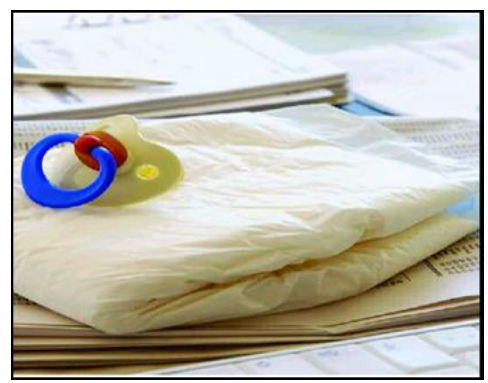

Şekil 1. Bebek bezi [1]

Bebek bezinin temel fonksiyonu, bebeğin 2-3 yaşına kadar idrar ve dışkısını emerek kuru bir yüzey sağlamasıdır. Günümüzde Avrupa pazarının \%90'1 yapışkanlı bezlerden oluşmaktadır. Alıştırma külotları ve pantolon şeklindeki bezler bebeklere tuvalet alışkanlığının kazandırıldığı zamanlarda kullanılır [1].

Bebek bezi boyutları bebek ve yeni doğan bebeklerin boyutları dikkate alınarak 0-36 ay arasında değişir. Türkiye'de bebek bezleri;

- Yeni doğan $(2-5 \mathrm{~kg})$

- Mini (3-6 kg)

- Midi $(5-9 \mathrm{~kg})$

- Maksi (8-18 kg)

- Junior (11-25 kg)

olarak 5 farklı ebatta üretilip kullanılmaktadır.

Günümüzdeki ürünler her tabakanın farklı fonksiyonları yerine getirdiği değişik katmanlardan oluşur. Bir bebek bezinde alt ve üst dokunmamış kumaş arasında emici bir tabaka bulunur. Bu tabakada bulunan süper emici polimerler, idrar ve 
dışkı enzimlerinin bebeğin cildinden uzak tutulmasını sağlarlar [4]. Bez çok adımlı bir işlemle üretilir. Birinci adımda emici tabaka istenilen emiciliğe getirilir. 2. adımda bu tabaka geçirgen üst tabaka ve geçirgen olmayan alt tabaka katmanlarının arasına yerleştirilir. Tabakalar 1S1 veya ultrasonik titreşimle yapıştırılır. Tabakaların kenarları bebeğin kalçasını ve bacağını düzgün bir şekilde sarması için elastik fiberlerle sabitlenir [1].

Bebek bezi üreticileri katma değerli özellikler sunarken çevreye dost düşük maliyetli dizaynlar üretme yolunda dokunmamış yüzey kullanımını önemli ölçüde artırmışlardır. Bebek bezlerindeki dokunmamış yüzey tüketimi esas olarak, genelde termal bağlama veya giderek artan bir biçimde spunbond polipropilen kumaşlar olan, üst yüz (topsheet) ve alt yüzden (backsheet ) oluşmaktadır. Fakat bebek bezinde giderek artan biçimde SMS (Spunbond-Meltblown-Spunbond) prosesi ile üretilen kumaştan yapılan bacak kenarı bariyerleri, airlaid (havalı serme) kompozit kumaştan üretilen çeşitli emici katmanları ve kalça bağcığı, streç panelleri gibi bazı küçük alanlar ve diğer kısımlarında da dokunmamış yüzeyler kullanır. Kullanılan bütün kumaşların fonksiyonlarını yerine getirmek için önemli özellikleri vardır. En önemlisi bu kumaşlar sıvıyı itmek ve kuruluğu sağlamak amacıyla ya hidrofob ya da hidrofildir [1].

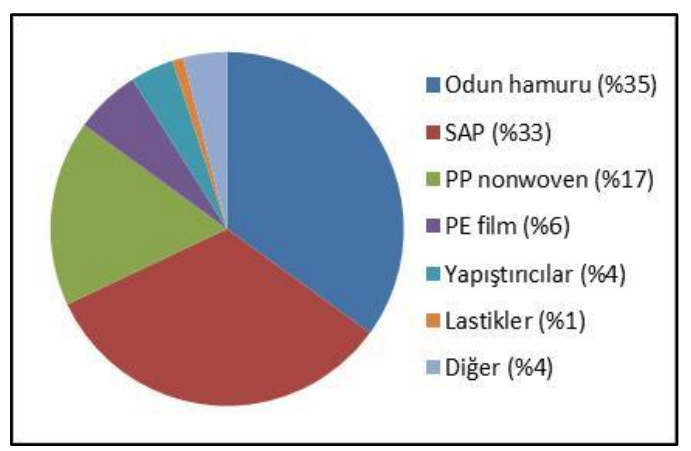

Şekil 2. Bebek bezi bileşenlerinin oranları [1]

Tüm bebek bezleri yaklaşı 40-42 gram ağırlığında olup başlıca odun hamuru (fluff pulp), süper emici polimer (SAP), polipropilen (PP), polietilen (PE) ve az miktarda bantlar (tapes), lastikler (elastics), yapıştırıcılardan (adhesives) oluşur (Şekil 2 ve Şekil 3) [1].

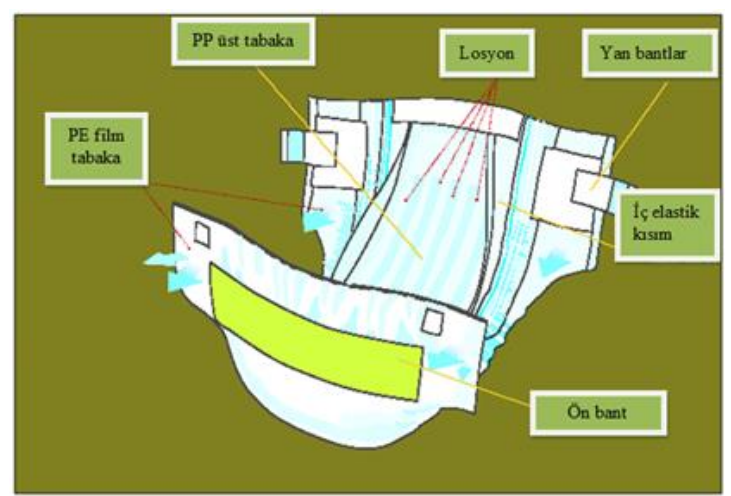

Şekil 3. Bebek bezi bileşenleri [1]

Bebek bezi bileşenleri; üst tabaka (topsheet), dağıtıc1 tabaka (acquisition/distribution layerADL), örtücü kumaş tabaka (tissue/core wrap layer), emici tabaka (absorbent core structure), arka tabaka (backsheet), yapıştırıcılar (adhesives), lastikler (elastics), yan bantlar (lateral tapes) ve ön bant (frontal tape), üst tabakaya eklenen losyonlar ve dekoratif dış tabaka olarak sıralanmaktadır.

\section{1. Üst Tabaka (Topsheet)}

Üst yüzeyin üzerindeki temas noktasından idrarın alt tabakaya hızlı bir şekilde transferini sağlar (Şekil 4). Polipropilen hammaddeli nonwoven yüzeyden yapılan bu tabaka bebeğin cildinin tahrişini önlemek için çok yumuşaktır. İdrarla ilk temas eden tabaka olduğu için sslanabilir olup ve yüksek sıvı geçirgenliğine sahiptir. Bebeğin cilt bakımı için bu tabakaya losyon uygulanmaktadır [5].

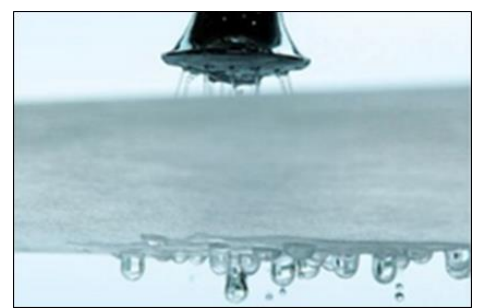

Şekil 4. Sıvının üstten alt tabakaya transferi [5]

Bezde kullanılan nonwoven yüzeyler genellikle spunbond prosesi ile üretilir. Ayrica termal bonded ve air bonded nonwoven tabakaların kullanımı da mümkündür. Spunbond nonwoven yüzeyler termal bonded yüzeylere göre daha yumuşak ancak daha düşük direnç ve mukavemete 
sahiptir. Air bonded yüzeyler ise spunbonda göre daha olukludur (lofty) [5]. Üst tabaka hidrofil ve hidrofob katmandan oluşur.

Hidrofobik nonwoven katman: Bariyer (leak guard) adıyla bilinen bu tabaka bacak kısımları için sızıntıyı önlemek amacıyla sıvı geçişine izin vermez (Şekil 5). Söz konusu katman yüzey aktif madde uygulanmayan polipropilenden yapılır [5].

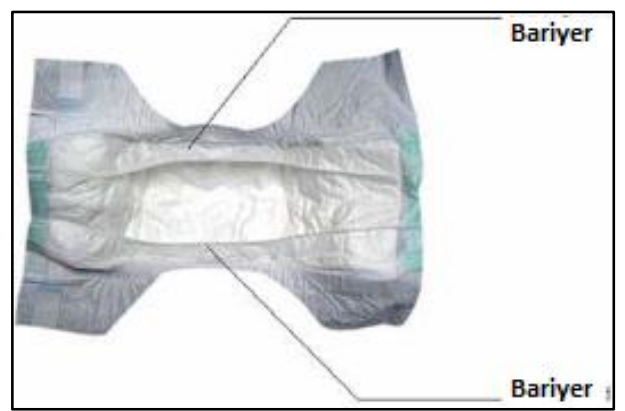

Şekil 5. Hidrofobik nonwoven tabaka (bariyer) [5]

Hidrofilik nonwoven katman: Topsheet olarak isimlendirilen bu katman ise bebeğin cildiyle asıl temas eden tabaka olup idrarın bezin iç kısımlarına iletilmesini sağlar (Şekil 6). Hidrofob katmanla aradaki tek fark yüzey aktif maddenin hidrofilleştirme amacıyla uygulanmasıdır [5]. Bu tabakalar bezde yaygin olarak $12-25 \mathrm{~g} / \mathrm{m}^{2}$ ağırlığında kullanılır.

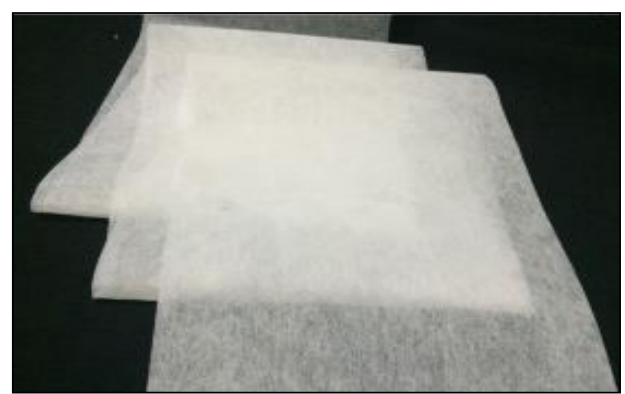

Şekil 6. Hidrofilik nonwoven tabaka [6]

\subsection{Dağıtıcı Tabaka(Acquisition/Distribution Layer-ADL)}

Üst tabaka ile emici tabaka arasında bir ara tabakadır. Bu kısım, emilmenin en iyi şekilde gerçekleşmesi için üst tabakadan idrarı alır ve dağıtıcı tabakada depolanmasını sağlar. Sıvının emici tabakaya hızlı bir şekilde hareket etmesi için emici tabaka ince olduğunda bu ara tabaka gereklidir. ADL tabakası, emici tabakadaki SAP oranı ağırlıkça yaklaşık \%15 ve civarı olduğunda kullanılmalıdır. Bezin tam uzunluğu boyunca kullanıldığı gibi bazen de resimdeki gibi hedef bölge yakınında bir yama gibi de kullanılabilir (Şekil 7 ve Şekil 8). Cilde kuruluk hissinin verilmesi için bu tabaka çok önemlidir. Bunun için farklı yap1 ve sayılarda materyaller kullanılır. ADL tabakası, ya kıvırcık lifli air bonded ya da yüksek loftlu nonwoven yüzeyden yapılır. Bezde genellikle 20-100 g/m² a ğırlığında kullanılır [5].

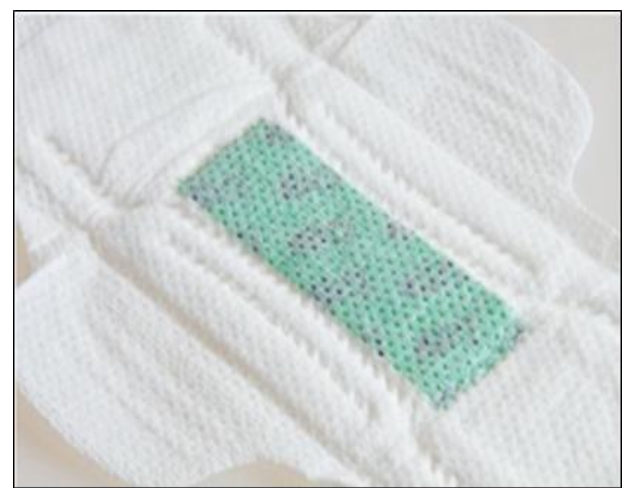

Şekil 7. Bez ortasına uygulanmış ADL [5]

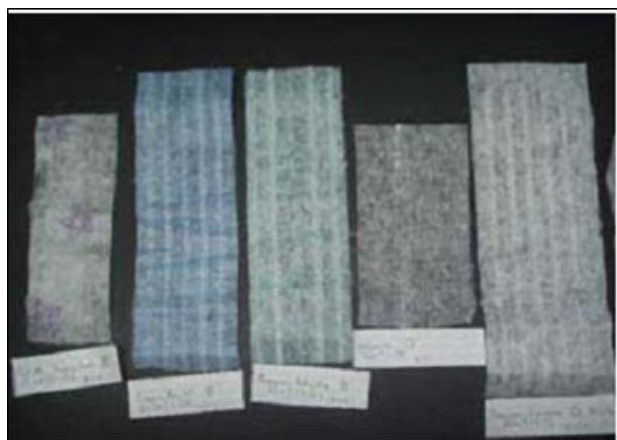

Şekil 8. Farklı ebatlarda ADL tabakaları [5]

\section{3. Örtücü Kumaş Tabaka (Tissue/Core Wrap Layer)}

Bazı bebek bezlerinde emici tabaka ve dağıtıcı tabaka etrafinda kullanılır. Üretim prosesine yardımcı bir işlem olup ped için taşıyıcı olarak kullanılır. Bezin tamamına eklenen bu kılıf süper 
emici polimerlerin iç plastik filme zararını azaltmaya yardımcı olur. $\mathrm{Bu}$ tabaka kâğıt malzemeli olursa tissue adiyla bilinir ve genellikle $16 \mathrm{~g} / \mathrm{m}^{2}$ ve üzeri gramajda kullanılır. Malzeme SMS nonwoven olursa bu tabaka core wrap olarak bilinir ve $12 \mathrm{~g} / \mathrm{m}^{2}$ ve altı gramajda kullanılır [5].

\subsection{Emici Tabaka (Absorbent Core Structure)}

İdrarın depolandığ 1 katman olup modern bebek bezinde anahtar bileşendir. Üst tabakadan transfer edilen ve dağıtıcı tabaka tarafından dağıtılarak bu tabakaya geçirilen idrar emici tabakada hapsedilir. Bezlerde kullanılan pamuk materyali iyi bir emicidir fakat bazı sentetik polimerler doğal liflerin emme kapasitesini aşmaktadır. Günümüzde bezlerin kendi ağırlığının 15 katı Sıvı absorplaması hedeflenmektedir. $\mathrm{Bu}$ emme kapasitesi bezin merkezinde bulunan emici pedin özelliklerine bağlıdır. Modern bebek bezlerinde bu tabakada odun hamuru gibi fibrilleştirilmiş materyal ve hidrofil süper emici polimerler (SAP) olmak üzere iki ana bileşen vardır [5].

\subsubsection{Selülozik Tabaka (Fluff Pulp)}

İlk zamanlarda bebek bezi merkezi \%100 odun hamurundan oluşmaktaydı. Bu kısım sünger gibi olup sonuçta çok küçük bir basınçla doymuş olan tabaka emilen sıvının geri birakılmasına veya sızmasina neden olurdu [5]. Bezin yapısında kullanılan odun hamuru tamamen selülozdur (Şekil 9). Bakımlı ormanlardaki çam ağaçlarından elde edilir. Bezde kullanılan tipik elyaf uzunluğu yaklaşık 2,6 mm'dir [5].

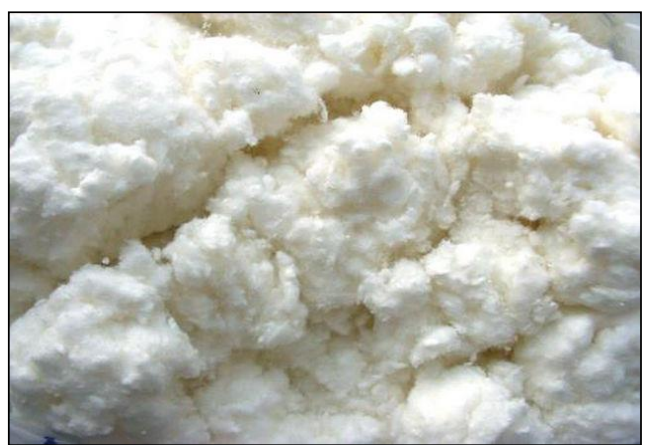

Şekil 9. Selülozik tabakayı oluşturan lifler [7]
Sıvı, lifler arasındaki kılcal boşluklara ve su-elyaf arasındaki yüzey tansiyonuna bağlı olarak emilir. Pulp serbest halde (free swell) iken gram başına 10 cc civarında su emerken $5 \mathrm{kPa}$ basinca maruz kaldığında 2 cc'den daha az su emer. Selüloza alternatif olarak sentetik liflerden yapılmış air laid yüzeyler emici tabaka olarak denenmektedir. Sentetik liflerden özellikle selüloz asetat ve polipropilen liflerinin emici tabakada kullanımı öne çıkmaktadır [5]. Selülozik tabaka (fluff pulp) bezde $5-15 \mathrm{~g} / \mathrm{m}^{2}$ ağırlığında kullanılır.

\subsubsection{Hidrofil Süper Emici Polimerler (SAP)}

Süper emici malzemeler, hijyen ve kişisel bakım ürünlerinde cildi kuru tutmak amacıyla kullanılan, kendi ağırlığının 100-200 katına kadar sıvıyı içerisine hapseden polimer esaslı malzemelerdir (Şekil 10). Günümüzde kullanılan süper emici polimerler sodyum akrilat, potasyum akrilat ya da alkil akrilat gibi çok küçük partiküllü çapraz bağlı poliakrilat polimerlerdir. Bu polimerler genellikle granül şeklinde kullanılırlar. Daha az odun hamuru kullanımı ve daha iyi performans sağlaması sayesinde daha ince ürünlere izin veren bu polimerler bezin siviyı tutma kapasitesini geliştirirler [5].

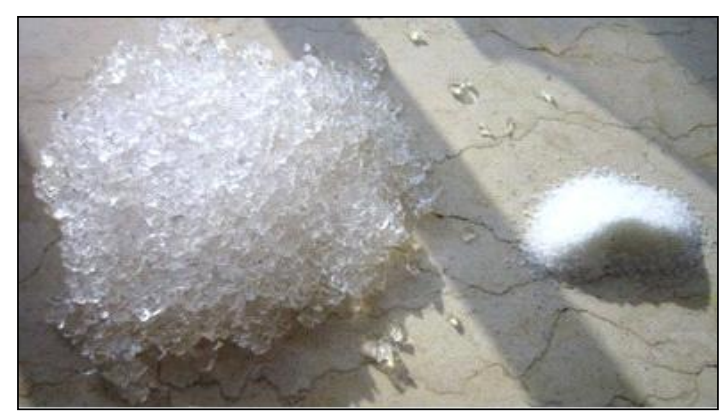

Şekil 10. Süper emici polimerlerin ıslanma öncesi ve sonras1 görünümü [8]

SAP, pulp ile aynı ağırlıkta veya odun hamurunun \%50-60'1 oranında pede ilave edilir. Bez merkezinin yaklaşı $\% 25-35$ 'i bu polimerlerden oluşup merkezin sıv1 hapsetme mekanizması olarak görev yaparlar. Odun hamuru ise bez merkezinin \%35'ini oluşturur. En çok kullanılan SAP, sodyum poliakrilat yapısındadır (Şekil 11). $\mathrm{SAP}$ suyla temas ettiği zaman $\mathrm{Na}$ polimerden 
ayrılır ve geride karboksil iyonları kalır. $\mathrm{Bu}$ iyonlar, negatif yüklü oldukları için birbirini iter ve böylece polimer, gevşeyerek açılır ve $\mathrm{Na}$ atomları tarafindan çekilen suyu absorplar (Şekil 12). Polimer aynı zamanda üç boyutlu etkisi veren çapraz bağlara sahiptir. Bir milyondan daha fazla olan yüksek molekül ağırlığından dolayı suyun absorplanmasıyla çözünmek yerine jel halinde katılaşır [5].

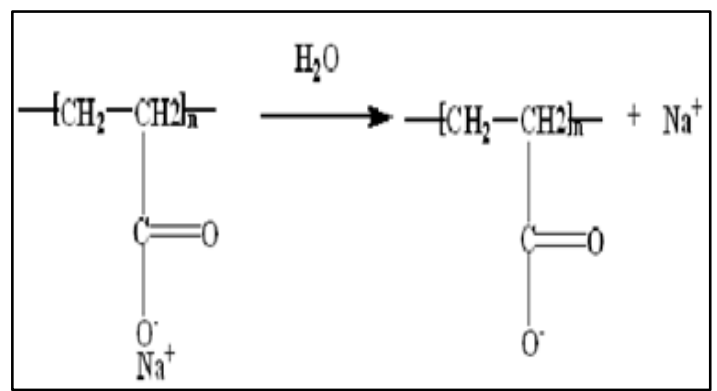

Şekil 11. Sodyumpoliakrilat

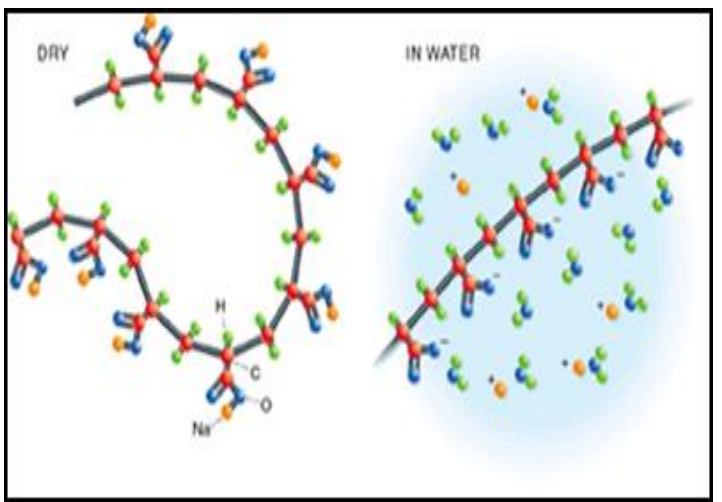

Şekil 12. SAP Polimerinin su absorplaması

\subsection{Arka Tabaka (Backsheet)}

$\mathrm{Bu}$ tabaka ya polietilen film tabaka ya da son zamanlarda nonwoven film kompoziti şeklindedir. Bezden sıvının sızmasını önler. Özellikle ıslandığında tüm yapının içeriğinde önemli bir rol oynar. Bu kısım beze temasta ilk ele gelen tabaka olup bu nedenle burada yumuşaklık önemli olarak algılanır. Amacına uygun olması için arka tabakanın yeterli sağlamlıkta ve aynı zamanda ince ve bebek hareket ettiğinde hışırtısız olması gereklidir. Arka tabaka, film tabakası üzerine eriyebilen toz yapıştırıcılar (hot melt) veya isı ve basınç kullanarak polipropilenden yapılmış nonwoven yüzeyin yapıştırılmasıyla kumaş şeklinde de olabilmektedir. Film yerine nefes alan kumaşlar da kullanılabilmektedir. Ancak bu kumaşlar gerçekte dokuma değildir, yine polipropilenden yapılmış nonwoven filmlerdir. Genellikle bezde $14-20 \mathrm{~g} / \mathrm{m}^{2}$ ağırlığında kullanılır [5].

\subsection{Yapıştırıcılar (Adhesives)}

Bunlar ped ve lastikler gibi bezin farklı bileşenlerini yapıştırmak için kullanılır. Çoğunlukla arka tabaka (backsheet) ve nonwoven yüzeyleri yapıştırmada normal yapıştırıcılar, bel ve bacak lastiklerini yapıştırmak içinse elastomerik yapıştırıcılar kullanılır. Bez çok ince olduğunda bezin 1slakken mukavemetini artırmak için ped bütünlüğünü sağlayan yapıştırıcı olarak bilinen özel yapıştırıcı kullanılır [5].

\subsection{Lastikler (Elastics)}

Bezin uygunluğunu geliştirmek için kullanılan lastikler genellikle poliüretan köpük, kauçuk ya da elastandan (likradan) yapılırlar. Bel ve bacak kısımlarında kullanılan bu lastikler aynı zamanda yan kisımlarda ve bantlarda da kullanılabilir (Şekil 13 ve Şekil 14). Çoğu sızdırmaz manşetler bebeğin bacaklarına uyum sağlaması için likrayı kullanmaktadır [5].

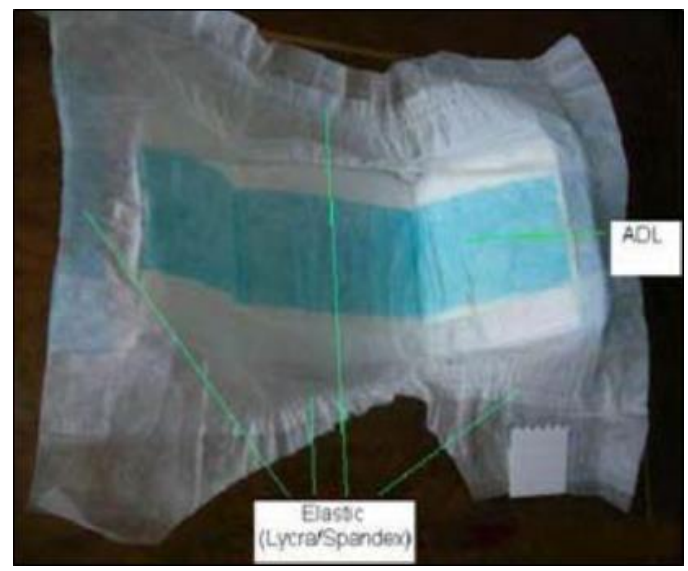

Şekil 13. Bezin bel ve bacak kısmında lastik kullanımı [5] 


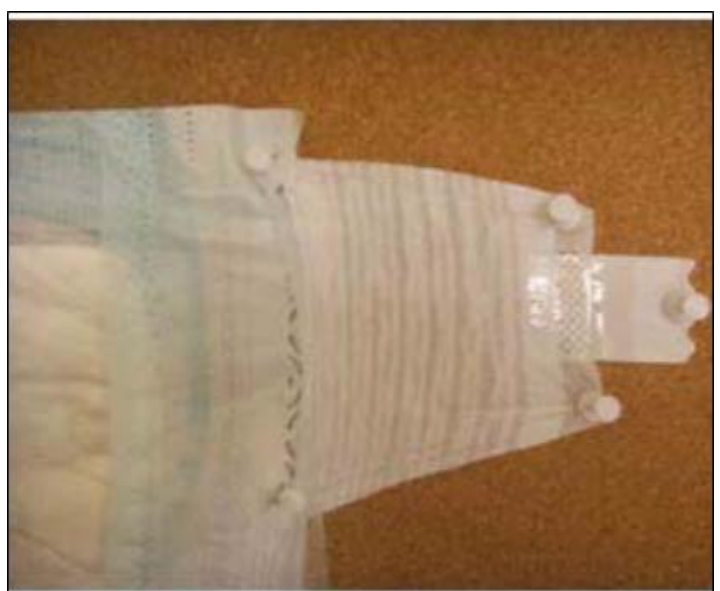

Şekil 14. Yapışkan bantta lastik kullanımı [5]

\subsection{Yan Bantlar (Lateral Tapes) ve Ön Bant (Frontal Tape)}

Yüksek kaliteli bebek bezlerinde mekanik yollar oluşturmak için kullanılan bu bantlar aynı zamanda 'kancalı bant' olarak bilinir. $\mathrm{Bu}$ amaçla polipropilenden yapılmış yapışkan bantlar kullanılır. Arka tabaka yırtılmaksızın yan bantların defalarca eski pozisyonlarına dönmesini sağlamak için kullanılan ön bant polipropilen filmden yapılır ve bezin ön kısmına yapıştırılır. Ön bant genellikle 45-70 g/m² ağırlığındadır [5].

\section{9. Üst Tabakaya Eklenen Losyonlar}

Üründe yenilikler yaratmak amacıyla nemlendirici ve güzel koku verici maddeleri içeren losyonlar nonwoven olan üst tabakaya eklenir. Aloe vera, D ve $\mathrm{E}$ vitaminleri, vazelin, badem yağı, yulaf ekstraktı, jojoba vs. bunlardan bazılarıdır. Ayrıca üçüncül amonyak ya da gümüş tuzu bileşimleri gibi maddeler de anitbakteriyel losyon olarak kullanılmaktadır [5].

\subsection{Dekoratif Dış Tabaka}

Farklılık yaratmak için bazı bezlerde güncel ya da iyi bilinen karakter resimleri içeren veya yatak çarşaflarına benzer resimler içeren dekoratif filmler kullanılır. Bu kısmın diğer bir işlevi ise 1slaklığ belirtmesidir [5].
Çizelge 1. Başlıca materyal tedarikçileri [9]

\begin{tabular}{|c|c|c|c|}
\hline Materyaller & \multicolumn{2}{|c|}{$\begin{array}{l}\text { Bez Başına } \\
\text { Kullanımı }\end{array}$} & Tedarikçiler \\
\hline $\begin{array}{l}\text { Fluff pulp (odun } \\
\text { hamuru) }\end{array}$ & $21 \mathrm{~g}$ & N/A & $\begin{array}{l}\text { Lenzing, SCA Forest } \\
\text { Products }\end{array}$ \\
\hline $\begin{array}{l}\text { Textile Backsheet } \\
\text { (SMS ya da } \\
\text { polietilen film) }\end{array}$ & $0,13 \mathrm{~m}^{2}$ & $20 \mathrm{~g} / \mathrm{m}^{2}$ & $\begin{array}{l}\text { Gülsan, General } \\
\text { Nonwovens, Pegas, } \\
\text { Dunour, Avgol }\end{array}$ \\
\hline $\begin{array}{l}\text { Topsheet (SS ya de } \\
\text { SSS spunbond, } \\
\text { thermobond ) }\end{array}$ & $0,1 \mathrm{~m}^{2}$ & $15 \mathrm{~g} / \mathrm{m}^{2}$ & $\begin{array}{l}\text { Gülsan, General } \\
\text { Nonwovens, Telasis, } \\
\text { Pegas, Dunour, Avgol }\end{array}$ \\
\hline $\begin{array}{l}\text { Leg cuff/ Bariyer } \\
\text { (SMS nonwoven) }\end{array}$ & $0,03 \mathrm{~m}^{2}$ & $20 \mathrm{~g} / \mathrm{m}^{2}$ & $\begin{array}{l}\text { Gülsan, Pegas, Dunour, } \\
\text { Avgol }\end{array}$ \\
\hline $\begin{array}{l}\text { Acquisition Layer } \\
\text { (ADL) }\end{array}$ & $0,04 \mathrm{~m}^{2}$ & $20 \mathrm{~g} / \mathrm{m}^{2}$ & $\begin{array}{l}\text { Freudenberg, Lyocell, } \\
\text { Telasis, Tradegar }\end{array}$ \\
\hline Lastikler/Likra & $0,13 \mathrm{~g}$ & N/A & $\begin{array}{l}\text { Dupont, Freudenberg, } \\
\text { Radici, Spandex }\end{array}$ \\
\hline $\begin{array}{l}\text { Frontal Tape (ön } \\
\text { bant) }\end{array}$ & $0,25 \mathrm{~g}$ & $45 \mathrm{~g} / \mathrm{m}^{2}$ & $\begin{array}{l}\text { Freudenberg, Lyocell, } \\
\text { Telasis, Tradegar }\end{array}$ \\
\hline SAP & $7 \mathrm{~g}$ & N/A & $\begin{array}{l}\text { Ameol, Atafia, BASF, } \\
\text { Bayer, Dow Chemical, } \\
\text { Degussa, Lysac }\end{array}$ \\
\hline Hot melts & $1,2 \mathrm{~g}$ & N/A & Bayer, Cognis \\
\hline
\end{tabular}


Çizelge 1'de dünyada bebek bezi için başlica materyal tedarikçileri ve bez başına kullanım miktarları verilmiştir. Başlıca Avrupa ve Amerika'da faaliyet gösteren firmaların çoğunlukta olduğu materyal tedarikçilerinde nonwoven ürünlerin tedarikinde Türkiye'den de iki firma ön plana çıkmıştır. Gaziantep’te faaliyet gösteren Gülsan ve General Nonwovens firmaları topsheet, bariyer ve backsheet tedarikinde dünyada oldukça önemli bir konumdadır.

\section{BEBEK BEZİ ÜRETIMI}

Atılabilir bezler kontinü işlemlerle üretilir. Bebek bezi makineleri yapılacak ürünün karmaşıklığına ve hıza bağlı olarak genellikle 20-45 metre uzunluğundadır (Şekil 15). Tipik üretim aralığ1 300-600 çocuk bezi / dakikadır. Ancak bazı büyük şirketlerin makinelerinde 1000 adet / dk ya kadar üretim yapılabilmektedir.

Bezlerin üretiminde 3 temel proses vardır. Bunlar:

- Odun hamurunu fibrilleştirme (defibrasyon), süper emici polimer (SAP) ekleme ve emici ped oluşumu (Şekil 16).

- Nonwoven yüzeylerin, filmlerin ve lastiklerin laminasyonu (Şekil 17).

- Şekil verme, kesme, katlama ve paketleme.

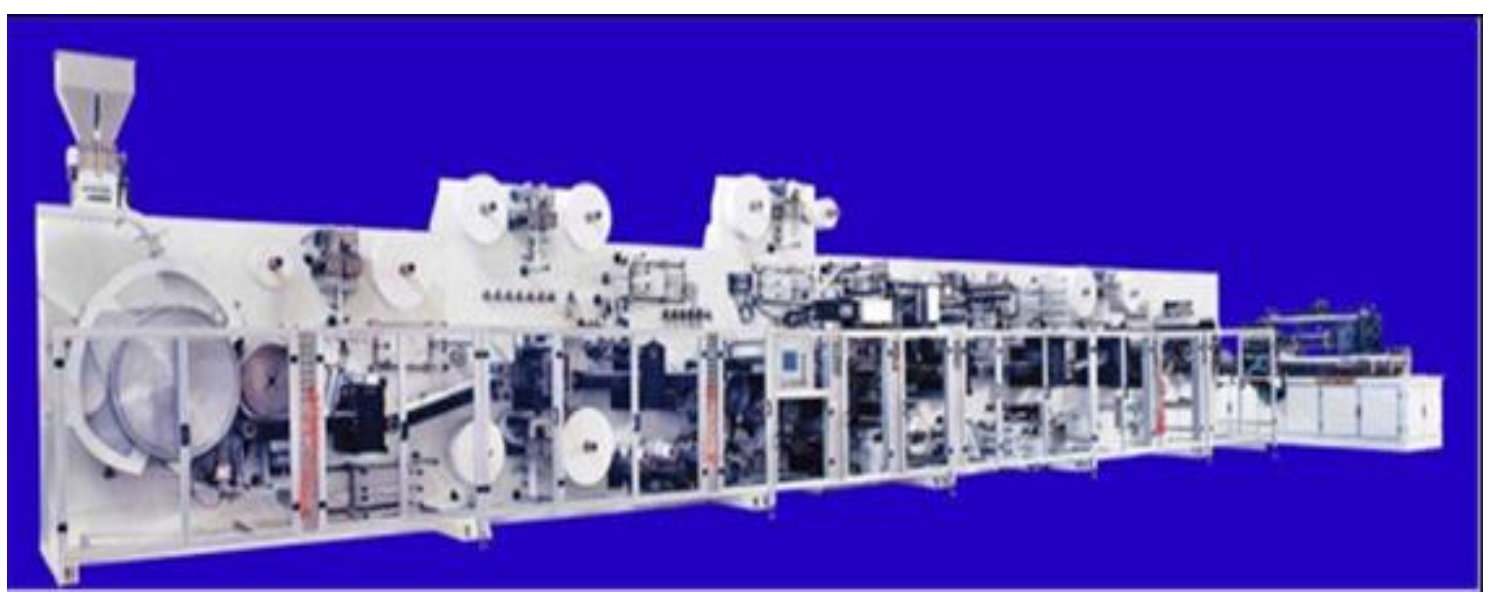

Şekil 15. Sürekli bebek bezi makinesi [9]

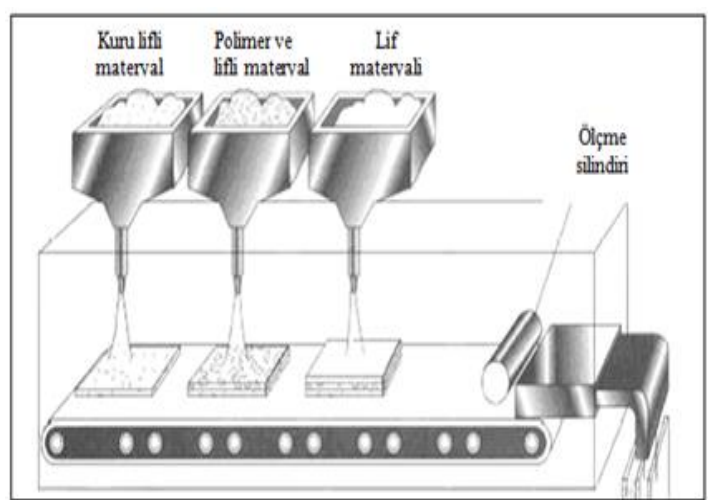

Şekil 16. Bebek bezi üretiminde 1. ana proses [1]

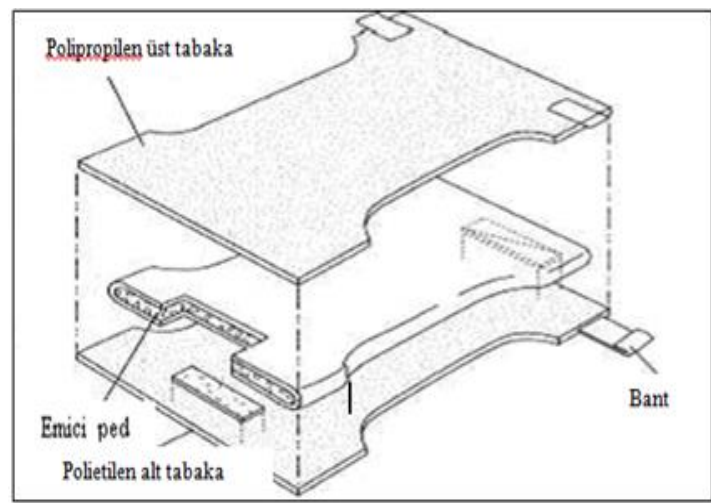

Şekil 17. Bebek bezi üretiminde 2. ana proses [1] 
Günümüz modern makinelerinde işlem verilmiş olup, makine kısımları iş akışına göre aşamalarına göre makine bölümleri Şekil 18 'de tanıtılacaktır [10].

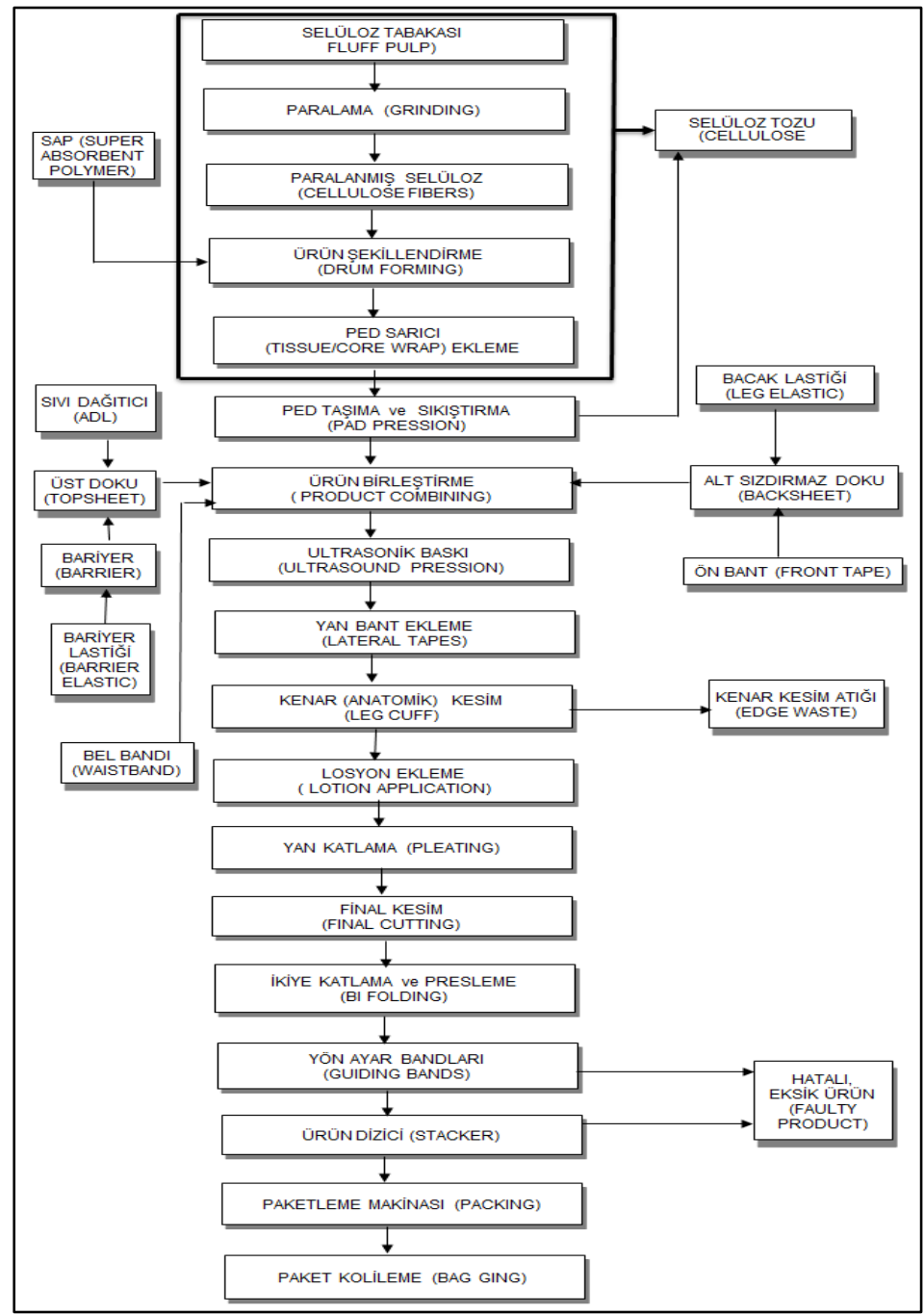

Şekil 18. Modern bebek bezi üretiminde iş akışı (Fameccanica) [10]

\subsection{Selüloz Standı}

Stantta bulunan silindire selüloz (pulp) ruloları takılır. Ayrıca paralayıcı üniteye girmeden önce selülozu su ile nemlendirmek için sprey sistemi mevcuttur. Elektronik olarak kontrol edilen stant, tabaka formundaki selüloz hamurunu besler (Şekil 19).

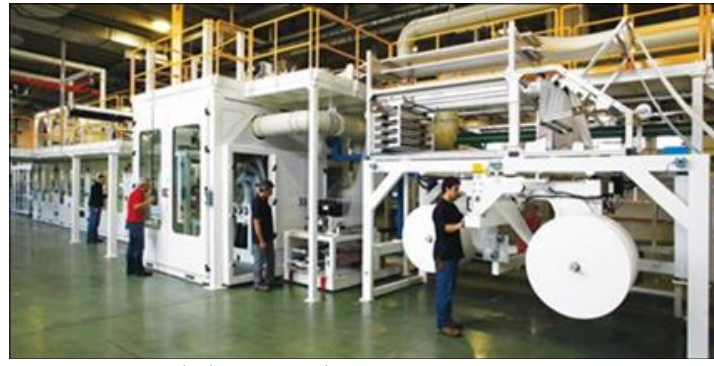

Şekil 19. Selüloz standı [12] 


\subsection{Paralayıcı Ünite (Pulp Grinder)}

Paralayıc1, besleme silindirinden gelen odun hamurunu kolaylıkla parçalayabilen dişlerle donatılmıştır. Paralayıcı ünitede, mukavva halindeki selülozik tabaka didiklenerek 2,4-2,8 mm uzunluğunda liflere dönüştürülür.

\subsection{SAP Dozajlama Aplikatörü (Super Absorbent Applicator)}

Bezin büyüklüğüne bağlı olarak toz halindeki SAP emicilik için selüloz liflerinin üzerine uygulanır. $\mathrm{Bu}$ ünite SAP tozlarının ürün şekillendirme tamburuna direkt olarak istenilen gramajda verilmesini sağlar.

\section{4. Ürün Şekillendirme (Drum Forming- Diaper Forming Unit)}

Ürün şekillendirici tambur üzerinde muska, üçgen $\mathrm{vb}$. formlarda kalıplar olup paralama ünitesinden gelen selüloz bu kalıplara yerleşir. Kalıbın şeklini alan selüloz üzerine SAP dozajlama ünitesinden gelen SAP eklenerek emici ped oluşumu sağlanır (Şekil 20).

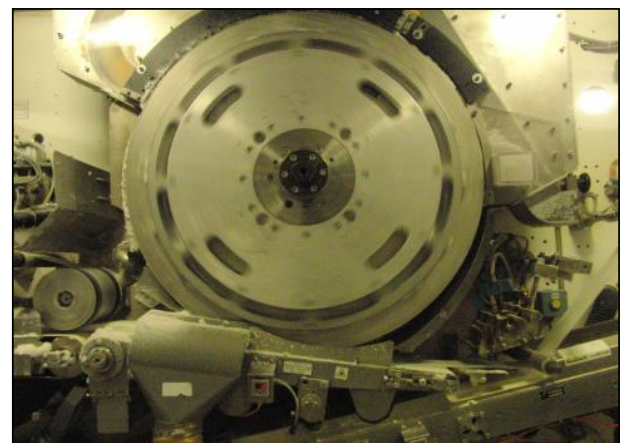

Şekil 20. Ürün şekillendirici tambur (Drum)

\subsection{Ped Sarıcı (Tissue/Core Wrap) Ekleme}

Tamburdan kalıp halinde çıkan lif ve SAP, tutkallanan alt kumaş doku (tissue) tabakasına taşıyıcı bant üzerinde yerleşir, bu ilerleme esnasinda lif ve SAP hapsolacak şekilde üst kumaş doku (tissue) ile üzeri kapatılır. Alt dokunun kenar kısımları üst dokuyu sararak birleştirilen dokular montajlanır (Şekil 21). Bazı durumlarda pedin sadece alt kısmı tissue ile kaplanıp pedi ikiye katlamak suretiyle pedin etrafinın tissue ile sarılmas1 yapılmaktadır. Yani emici pedin etrafi selülozik kumaş (core wrap) veya kâğıt (tissue wrap) ile çevrelenir. Paralama sırasında ve tissue ile kaplanma sirasında selülozik tabakalardan çıkan toz, uçuntu vb. emiş sistemi vasıtasıyla toz toplama ünitesine gönderilir.

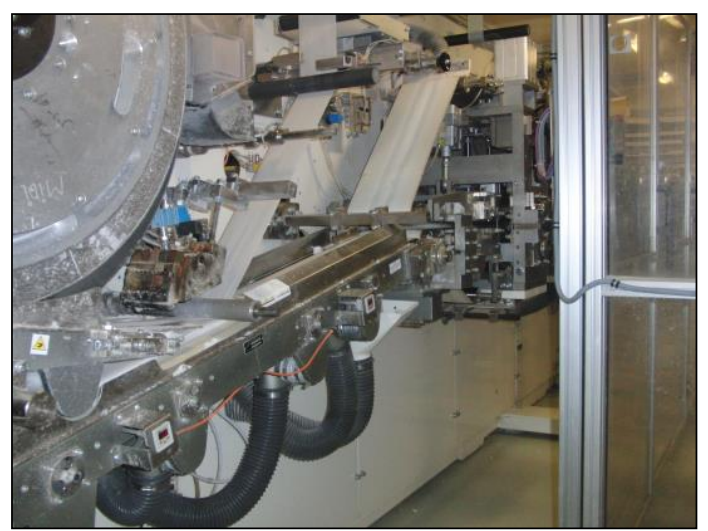

Şekil 21. Emici pedin çevrelenmesi

\subsection{Ped Baskı Ünitesi (Pad Pression Unit)}

Tissue ile kaplanan emici ped, istenen kalınlığa getirmek için öncelikle baskı silindirlerinden geçirilerek ezilir (Şekil 22). Hemen ardından da baklava dilimi biçimindeki silindirden geçirilerek (Şekil 23) bezde sıvının akışını sağlayan kanallar oluşturulması ve bu sayede sıvının pedin her noktasına eşit dağılması sağlanır. Pedin boyunda ve eninde boyut değişikliği olmaz.

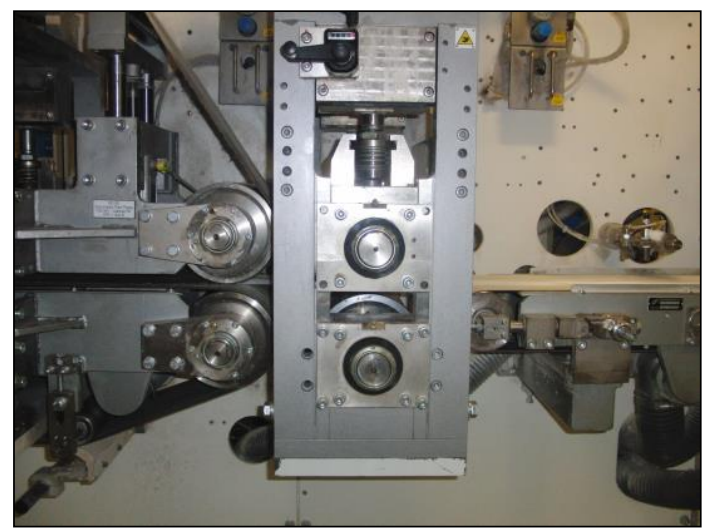

Şekil 22. Bask1 silindiri 


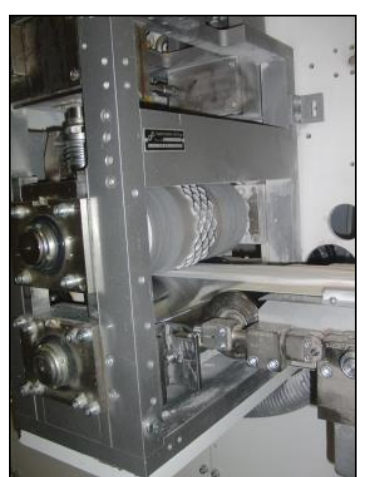

Şekil 23. Sıvı kanalı oluşturan baskı silindiri

\subsection{Lastik ve Bant Aplikatörleri (Elastic and Tape Applicators)}

Öncelikle ön bant (Şekil 24), kesici ve yer aplikatörü kullanılarak alt sızdırmaz dokuya (backsheet) eklenir. Bu materyalleri yapıştırmak için sprey formunda veya çok yollu olarak eriyebilen toz yapıştırıcılar (hot melts) kullanılır. Ped çok ince yapıldığından pedi sağlamlaştırmak için özel yapıştırıcılar kullanılır.

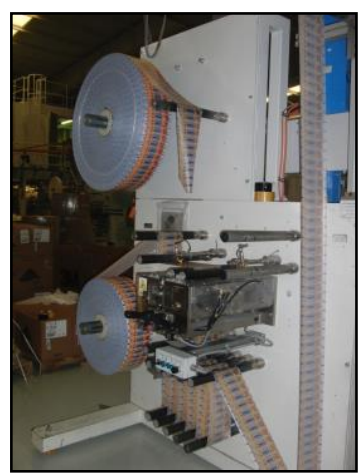

Şekil 24. Ön bant

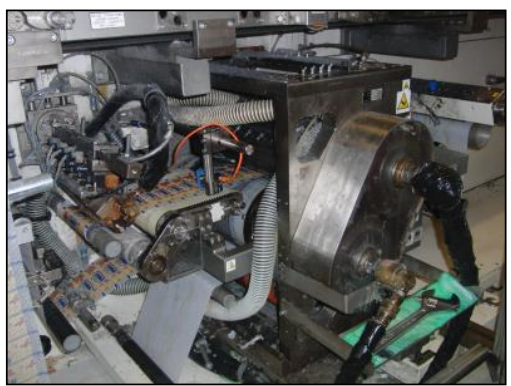

Şekil 25. Ön bant ve alt doku birleşimi
Şekil 25 'te görüldüğü gibi ilerleme esnasında ön bant polietilen alt dokunun (backsheet) üst kısmında belirlenen ölçüde kesimi yapılarak yapıştırılır. Bant üzerinde ilerleyen hammadde birleşimine devam ederken üst doku olan topsheet kısım bandın üst tarafındadır. Bu doku üzerinde belirlenen yere tutkallanarak sıvı dağıtıcı katman (ADL) yerleşir. ADL tabakası bezde üst doku (topsheet) ile ped arasında kalacak şekilde üst dokunun alt yüzüne yapıştırılır. Bel ve bacak bölgesine streç formu vermek için lastikler de bu noktada eklenerek eriyebilen toz yapıştırıcılarla (hot melts) yapıştırılır. Bezde kullanılan tipik lastikler likra, poliüretan veya poliester köpüklerdir (Şekil 26).

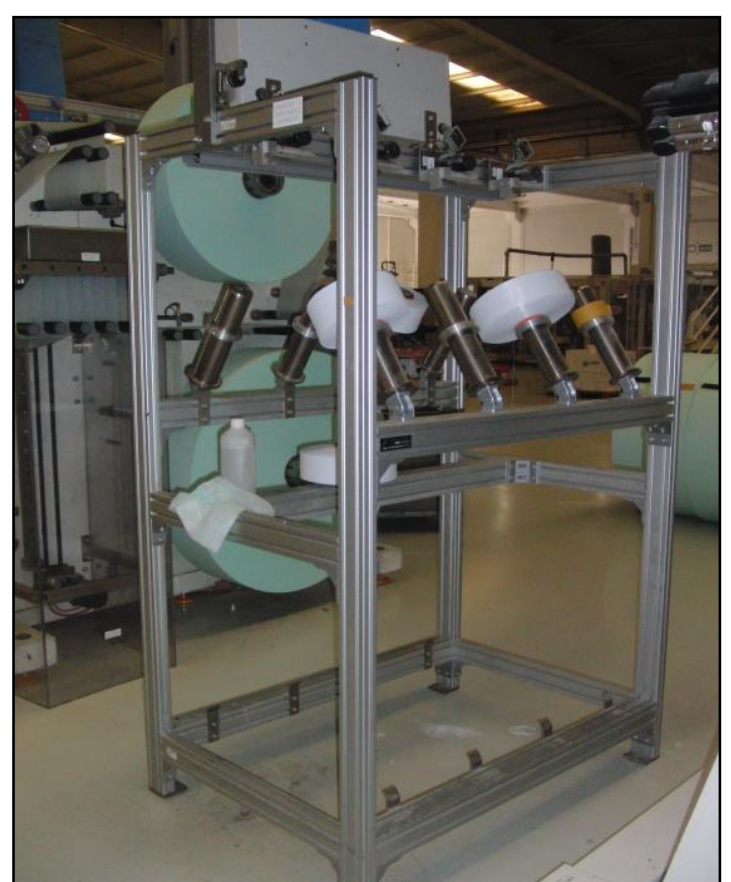

Şekil 26. Lastik stand1

\subsection{Alt Doku-Üst Doku-Bariyer Birleştirme için Fiksaj Grubu (Fixing Group for Product Combining)}

Hidrofob karakterdeki sızdırmaz alt doku veya polietilen film tabaka (backsheet) pedin altına, düşük yoğunluklu polipropilenden yapılmış SMS nonwoven k1lıf (topsheet) ise üstüne eklenir (Şekil 27, Şekil 28). 


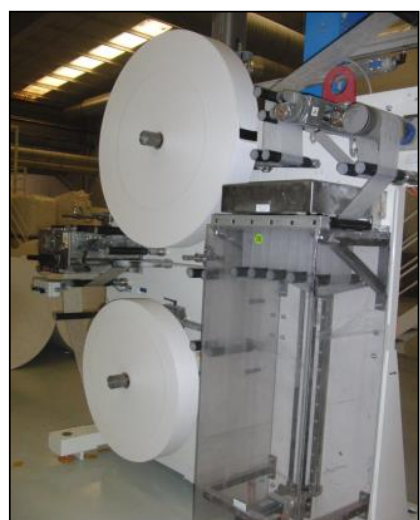

Şekil 27. Üst doku (Topsheet) stand1

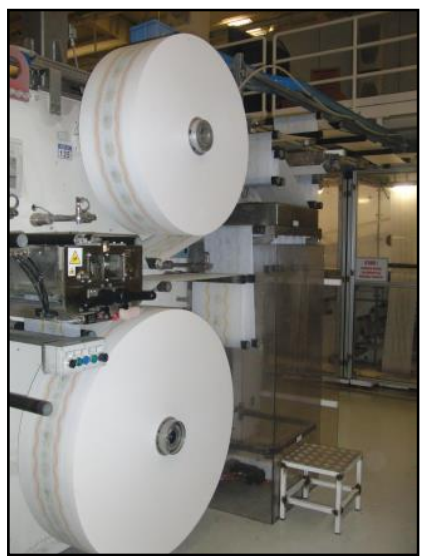

Şekil 28. Alt doku (Backsheet) standı

Hidrofob karakterdeki nonwoven bariyer kumaşı (Şekil 29), standından makineye beslenir. Kenarlarına bariyer lastiği uygulanan bariyer kumaşı ortadan ikiye kesilerek bezin iki tarafina yapıştırılır (Şekil 30).

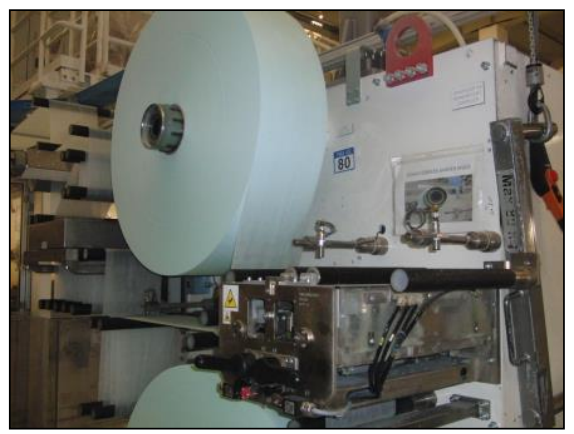

Şekil 29. Bariyer stand1

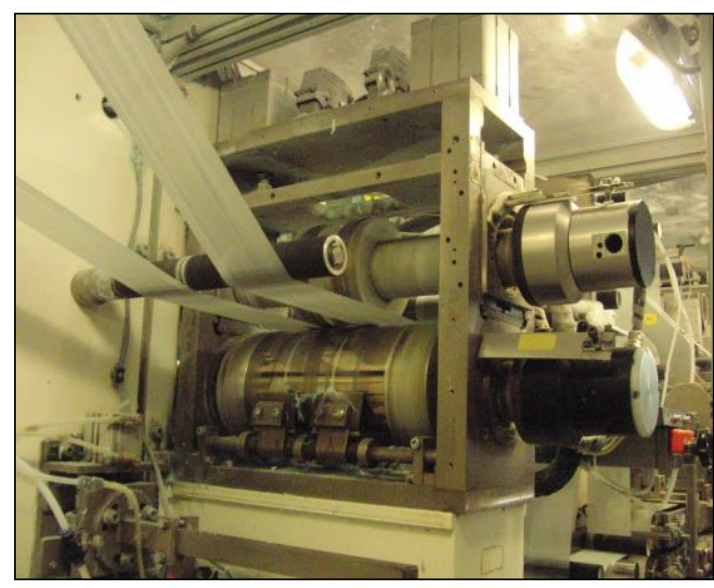

Şekil 30. Bariyer kapama ezmesi

\subsection{Ultrasonik Baskı Grubu (Ultrasound Pression) ve Yan Bant Aplikatörü (Lateral Tape Applicator)}

Parçaları birleştirilen bez daha iyi bir sabitleme etkisi için ultrasonik ses sistemi vasıtasıyla sıkıştırılır (Şekil 31). Üretim prosesindeki sonraki adım yan bantların eklenmesidir. Yine kesici ve bant aplikatörü kullanılarak uygulanır (Şekil 31).

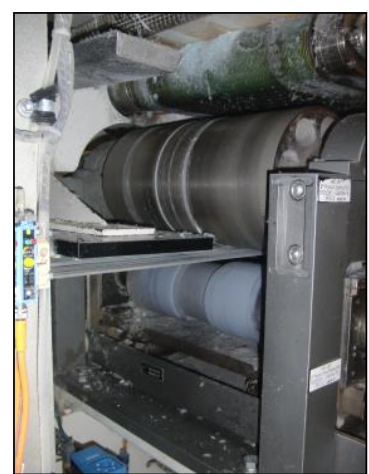

Şekil 31. Ultrasonik ses sistemi ve yan bant standı

\subsection{Anatomik Bez Kesim Grubu (Anatomic Diaper Cutting Group-Leg Cuff) ve Losyon Ekleme (Lotion Applicator)}

Bantlar eklendikten sonra kesim sistemiyle bezin bacak kısımları kesilir ve artıklar vakumlanarak çıkarılır (Şekil 32). Anatomik kesimden sonra bezin orta kısmına losyon eklenir (Şekil 33). 


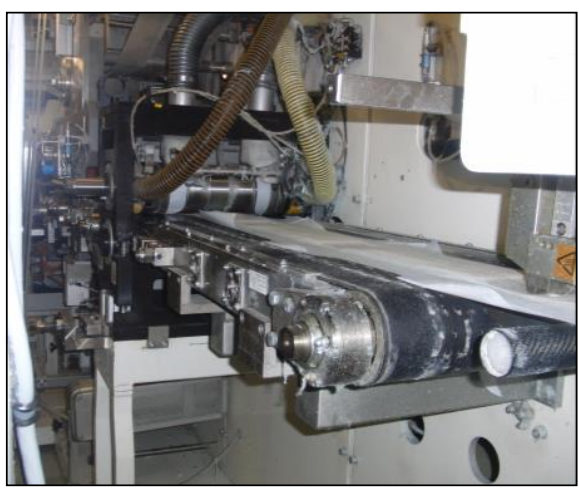

Şekil 32. Anatomik kesim (bacak kesimi)

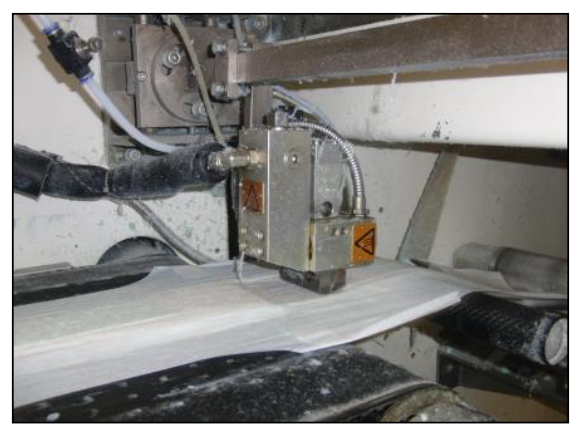

Şekil 33. Losyon ekleme

\subsection{Katlama, Son Kesme ve Presleme Grubu (Pleating, Final Cutting and Pressing Group)}

Bezin yan kısımları ortaya doğru katlanır. Ardından her biri bir adet bez oluşturacak şekilde parça kesimi yapılır, sonra ikiye katlanır (Şekil 34) ve kolay ambalajlamak için preslenir.

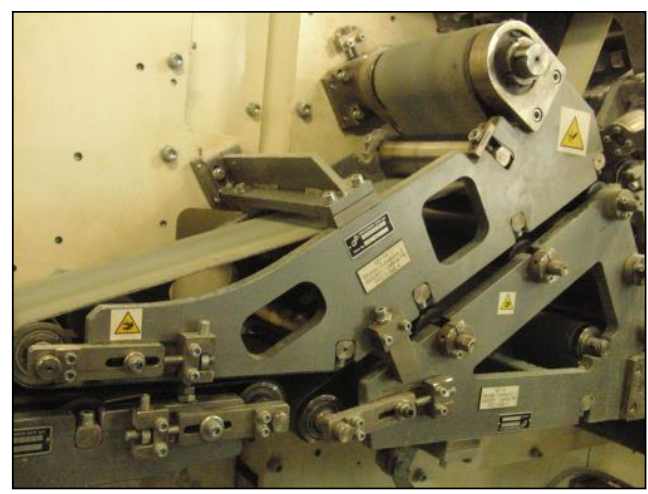

Şekil 34. Bez katlama

\subsection{Yön Ayar Bantları (Guiding Bands)}

Üretimi tamamlanan bezlerin kontrolü yapılır. Hatalı veya eksik ürün varsa hatalı ürün bandına yönlendirilir. Hatasız ürün ise stacker ünitesine gönderilir.

\subsection{3. Çıkarma ve İstifleme Grubu (Take Out And Stacking Group)}

Bezler otomatik olarak makineden çıkarılır ve stacker (Şekil 35) ünitesinde ürünler dizilir, sayılır ve sıkıştırılarak paketlemeye hazır hale gelir. Ürün kontrolü ile hatalı ürün varsa çıkarılarak pakete girmesi önlenir.

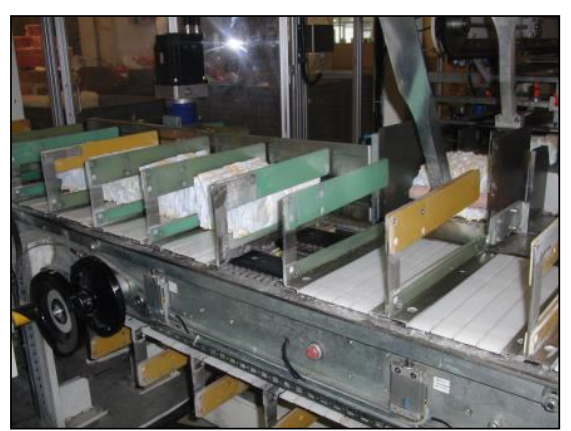

Şekil 35. İstifleme ünitesi (Stacker)

\subsection{Bez paketleme ünitesi (Diaper Packing Table)}

Bezler kutular veya torbalar halinde paketlenir (Şekil 36).

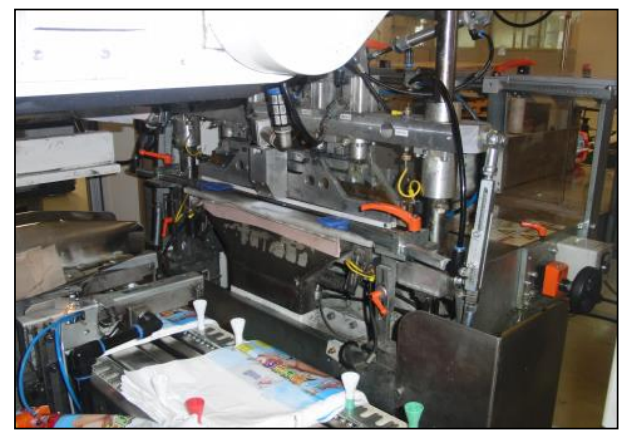




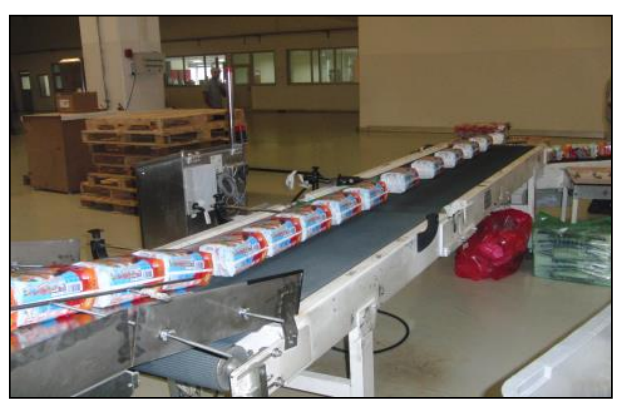

Şekil 36. Bez paketleme

\section{PAZAR DURUMU}

Küresel hijyenik ürünler; bezler, koruyucu ürünler, sslak mendiller, alt açma ve yetişkin bezleri ile kulak temizleme çubuklarından oluşur. Yaygın olarak dünyada üretilen hijyenik ürünlerin en büyük kısmını \%46 satış oranı ile bezler oluşturmaktadır. Bezleri \%35 satış oranı ile koruyucu ürünler izlemektedir. Şekil 37'de hijyenik ürünler açısından pazarı oluşturan ürünlerin satış oranları görülmektedir.

Türkiye'de bebek bezi pazarının büyüklüğü yaklaşık 350-400 milyon Euro olarak hesaplanmaktadır. Türkiye'de ailelerin \%84'ü hazır bezi tercih etmektedir. Ancak Avrupa'da günde 4-5 bez tüketilirken Türkiye'de $3 \mathrm{kez}$ alt değiştirilmektedir. Türkiye'de ortalama bez kullanım süresi 27 ay iken bu süre Avrupa'da daha uzun olup en uzun bez kullanım süresi Japonya'dadır. Günlük bez kullanım sayısı yeni doğan bebeklerde günde 8 adet, büyük bebeklerde günde ortalama 4 adet olup bu sayılar yine Avrupa ortalamasının altında kalmaktadır [11].

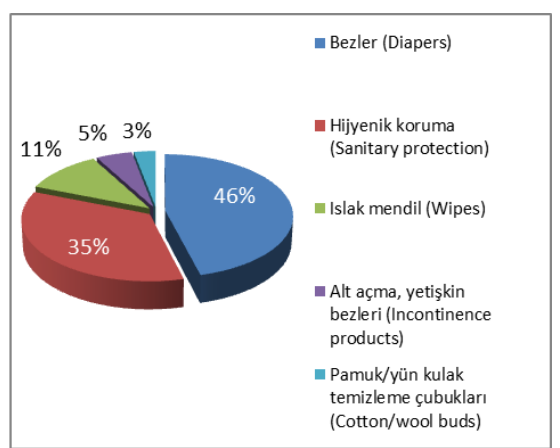

Şekil 37. Hijyenik ürünlerin pazar payları [12]
Çizelge 2'de dünyada pazara hâkim olan ilk on firma verilmiştir [9]. Söz konusu ilk on firmanın yedisi Çin'de faaliyet gösterirken iki firma Amerika'da bir firma ise Japonya'da faaliyet göstermektedir. ABD kökenli firmalar aynı zamanda Türkiye'de de faaliyette bulunmaktadır.

Çizelge 2. Dünyada başlıca bebek bezi üreticileri

\begin{tabular}{|l|l|l|}
\hline Şirket & Marka & Ülke \\
\hline Procter\&Gamble & Pampers & ABD \\
\hline Fujian Hengan & An erle & Çin \\
\hline Unicharm & Mami poko & Japonya \\
\hline Chiaus & Chiaus & Çin \\
\hline Kimberly-Clark & Huggies & ABD \\
\hline Guangdong & YINYIN & Çin \\
\hline Fuzhou Angel & Daddybaby & Çin \\
\hline AAB Group & Mignon Baby & Çin \\
\hline Fujian Hengli Group & Shuang Erbao & Çin \\
\hline Everybeauty Industrial & Sealar, Xiaotaoqu & Çin \\
\hline
\end{tabular}

Çizelge 3'te ise Türkiye'de faaliyet gösteren bebek bezi üreticileri markaları ve üretim yerinin bulunduğu il ile birlikte verilmiştir.

Çizelge 3. Türkiye'de başlıca bebek bezi üreticileri

\begin{tabular}{|l|l|l|}
\hline Firma adı & Marka & Yer \\
\hline P\&G & Pampers & Gebze \\
\hline KC & Huggieş & İstanbul \\
\hline Hayat Kimya & Molfix & İzmit \\
\hline Ontex & Canbebe & İstanbul \\
\hline Evyap & Evybaby & İstanbul \\
\hline SCA Y1ldız Grup & Love Baby & İstanbul \\
\hline Paksel & Bebiko & İstanbul \\
\hline KC-Ovisan & Pedo & İstanbul \\
\hline Hazel & Ninni Bebe & Uşak \\
\hline Eruslu & Sleepy & Gaziantep \\
\hline Pakten & Önlem /Joyful & Gaziantep \\
\hline Uderşan & Confy Baby & Gaziantep \\
\hline Sevinçler Group & Giggles & Gaziantep \\
\hline GBG & $\begin{array}{l}\text { Bunny baby, Twins } \\
\text { baby }\end{array}$ & Gaziantep \\
\hline Aksan & Smart baby, Pudy baby & Gaziantep \\
\hline Tat Kimya & Babydex & Gaziantep \\
\hline Damlanur Tekstil & Slasi, Neno, Elvis baby & Gaziantep \\
\hline
\end{tabular}

Çizelge 4'te Türkiye'nin bebek bezi ihracatında ilk on sırayı alan ülkeler ve satış rakamları dolar cinsinden verilmiştir. Çok büyük bir farkla en fazla ihracatın Irak'a yapıldığı görülmektedir. Irak'a yapılan ihracat, her y1l yaklaşık \%20-50 oranında bir artış göstermiştir. 2013 yılı itibariyle Irak’1 Azerbaycan ve Misır birbirine yakın rakamlarla izlemektedir. Çizelgeye göre Ukrayna, İsrail ve G. 
Afrika'ya yapılan bebek bezi ihracatı yıllar itibariyle gitgide azalırken diğer ülkeler inişli çıkışlı bir grafik sergilemektedir. Nijerya ve
Tacikistan'a 2012 yılında başlayan ihracatın yüksek olması ve artan eğilim göstermesi dikkat çekmektedir.

Çizelge 4. Türkiye bebek bezi ihracatı [15]

\begin{tabular}{|l|r|r|r|r|r|}
\hline Ülke & $2008(\$)$ & $2009(\$)$ & $2010(\$)$ & $2012(\$)$ & $2013(\$)$ \\
\hline Irak & 54.655 .245 & 81.565 .766 & 127.509 .413 & 171.574 .000 & 202.061 .483 \\
\hline Azerbaycan & 19.350 .570 & 21.842 .793 & 25.245 .994 & 28.979 .000 & 49.221 .944 \\
\hline Misir & 3.379 .651 & 9.775 .032 & 11.934 .279 & 61.577 .000 & 45.440 .685 \\
\hline Gürcistan & 10.193 .949 & 13.227 .830 & 12.377 .443 & 15.009 .000 & 25.876 .175 \\
\hline Nijerya & - & - & - & 9.673 .206 & 20.174 .041 \\
\hline Tacikistan & - & - & - & 17.100 .000 & 19.619 .267 \\
\hline Rusya & 21.950 .529 & 30.522 .478 & 25.005 .638 & 14.346 .000 & 19.453 .003 \\
\hline Ukrayna & 17.642 .105 & 20.071 .427 & 17.841 .763 & 5.701 .764 & 6.464 .462 \\
\hline İsrail & 20.135 .181 & 17.241 .600 & 24.343 .991 & 6.777 .261 & 6.006 .970 \\
\hline G. Afrika & $17.414 .23 \mathrm{~S}$ & 10.732 .815 & 11.098 .541 & 5.520 .000 & 4.161 .531 \\
\hline
\end{tabular}

\section{SONUÇ}

Tek kullanımlık hijyenik ürünlerin en başında bebek bezleri gelmektedir. Bebek bezleri, bebeklerin sağlığ1 ve rahatlığ açısından uygun yapıda olmalıdır. Bu nedenle bebek bezi ile ilgili son çalışmalar bebeğin sağlığını koruma ve konforunu artırma açısından kullanılabilecek hammaddeler üzerine yoğunlaşmıştır. Özellikle emicilik üzerine yapılan çalışmalar ağırlık kazanmıştır.

Günümüzde bebek bezleri başlıca üst tabaka, emici tabaka ve alt tabaka olmak üzere çok katmanlı bir yapıya sahiptir. $\mathrm{Bu}$ ürünlerde dokunmamış yüzey tekstillerin kullanımı, önemli derecede artmakta ve gelişmektedir. Bebek bezi üretimi, bezin tabakalarının belirli bir sıraya göre birleştirildiği ve bezde istenen özellikleri sağlayacak şekilde üniteler içeren sürekli makinelerde yapılmaktadır.

Türkiye'de bebek bezi üretimi İstanbul çevresi ile Gaziantep'te yoğunlașmış olup Irak bașta olmak üzere birçok ülkeye ihracatı yapılmaktadır. Bezde kullanılan dokunmamış (nonwoven) yüzeylerin üretiminde Gülsan ve General Nonwovens gibi ülkemizdeki bazı firmalar dünyada üst sıralarda yer almaktadir.

\section{KAYNAKLAR}

1. www.edana.org (Erişim tarihi: 10.01.2014).

2. Annapoorani, S.G., Nivedha, R.B., Devi, S.Y., 2016. Development of Disposable Baby Diaper with Microencapsulated Natural Fragrance
Finish. International Journal of Applied Research 2(7): 685-687.

3. Qian, C., 2011. A New Non-woven Material and its use in Functional Baby Diapers. Research Journal of Textile and Apparel, Vol. 15 Iss: 1, pp.66-71.

4. http://esatjournals.net/ijret/2014v03/i23/IJRET 20140323041.pdf, (Erişim tarihi: 25.10.2016).

5. Nagaswarna, R., Overview of Disposable Diaper Parts and Their Purpose, www.fibre2fashion.com/industryarticle/pdffiles/12/1124.pdf.

6. http://qzniso.en.made-inchina.com/product/ZKrEbtdTZBkR/ChinaDiaper-SSS-Nonwoven-for-Top-Sheet-withSGS-BM-001-.html (Erişim tarihi: 25.10.2016).

7. http://www.jjyoso.com/product/fluff-pulp/ (Erişim tarihi: 25.10.2016).

8. http://www.ecvv.com/product/3106279.html (Erişim tarihi: 25.10.2016).

9. www.disposablediaper.net (Erişim tarihi: 14.01.2014).

10. Fameccanica Katalog ve İşletme Verileri.

11. http://www.cbmeturkey.com/tr/genelbilgiler/sektöre-genel-bakis

12. www.nonwovens-industry.com (Erişim tarihi: 19.01.2014).

13. www.alibaba.com (Erişim tarihi: 20.01.2014).

14. Anonim.

15. www.tuik.gov.tr 
